\title{
THEORY IMPLEMENTATION OF NEED FOR HELP WIEDENBACH AND SELF CARE OREM IN PREGNANCY CASE WITH TUBERCULOSIS MULTI DRUG RESISTANCE
}

\author{
Kusila Devia Rahayu' ${ }^{1}$, Setyowati ${ }^{2}$ \\ ${ }^{1}$ STIKes Dharma Husada Bandung, Indonesia \\ ${ }^{2}$ Master Program of Nursing Science Faculty, Universitas Indonesia, Depok, Indonesia \\ Correspondence: kusila.rahayu@gmail.com
}

\begin{abstract}
Pregnancy with tuberculosis is classified as pregnancies with medical complicated non obstetrical and gynecological. Pregnancy with tuberculosis multi drug resistance occur in women who have a history of non compliance of treatment or treatment failure. Pregnancy with infection of mycobacterium tuberculosis multi drug resistance can cause pregnancy disturbance and fetal development disorder in the form of premature delivery and low birth weight. Five cases of pregnancy with tuberculosis multi drug resistance in this case study has been getting nursing care by applying the theory of need for help wiedenbach in the acute phase and self care Orem in the maintenance phase. The application of nursing theory proved to meet immediate relief needs and promote self-care potential clients so that interruption of pregnancy can be overcome and preterm delivery did not occur. Specialist of maternity nursing have an important role in the management of nursing care of pregnancies with complicated, therefore maternity nurses need to improve the knowledge and clinical skills on an ongoing basis.
\end{abstract}

Keywords: Multidrug resistance, Self-care, Tuberculosis, Wiedenbach

\section{INTRODUCTION}

Pregnancy with tuberculosis can cause disruption to pregnancy and fetal development disorder. Depkes RI (2008); Munir (2009); Cunningham (2010); PDPI (2012); Rogayah (2014) explains that multi drug resistance tuberculosis (MDR-TB) is caused by infected of mycobacterium tuberculosis with at least two first-line anti-Tuberculosis drugs : Rifamficin and Isoniazid.

Riskesdas (2013) reports that tuberculosis is a major global health problem, so its control becomes a shared commitment and its contained in the Millennium Development Goals 2015 and Sustainable Development Goals 2030 goals.

The WHO report (2009) explains that countries with the highest number of tuberculosis are India (2.4 million), China (1.6 million), southern Africa (0.59 million), Nigeria (0.55 million) and Indonesia (0.52 million). 
Characteristics of mycobacterium tuberculosis that can be restrained and do not show signs and symptoms in the long term make tuberculosis treatment needs to be done at least for six months without pause. The Association of Indonesian Lung Doctors (2012) explained that tuberculosis treatment needs to be done thoroughly for at least six months without pause and the incidence of anti-tuberculosis treatment cessation before six months is known as drug withdrawal.

According to Munir (2009) MDR-TB treatment at referral hospitals in Indonesia mostly has a history of dropped treatment with successful treatment percentage (20.4\%), treatment failure (27\%) and dropped treatment (34.5\%). Kemenkes (2011) explained that the incidence of dropped out treatment will make mycobacterium tuberculosis become invitro resistant and turned into a mutant.

Cunningham (2010) explains that microbiology of mycobacterium mutant tuberculosis will cause worsening of health conditions that are more severe than the health deterioration caused by ordinary tuberculosis infection.

The Association of Indonesian Lung Doctors (2012) explains that the health deterioration symptoms of MDR-TB are shown in the form of severe respiratory distress, malnutrition and massive weakness, thus risking pregnancy disorder and fetal development disturbance in the form of preterm labor and low birth weight.

The deterioration of pregnancy health and the risks of fetal distress make pregnancy cases with tuberculosis categorized as pregnancy with non obstetric and gynecological medical complications (Kemenkes RI, 2013). The magnitude of the effects of tuberculosis infection on pregnancy leads to pregnancy with MDR-TB requiring intensive care of maternity nurses. 
The application of Wiedenbach's need for help theory and Orem's self-care theory in pregnancy with multi drug drug resistance help maternity nurses in managing nursing care in the acute phase and maintenance phase. This case study aims to provide an overview of the nursing process in five cases of pregnancy with multi-drug resistant tuberculosis using the theories of need for help Wiedenbach and Orem self care.

\section{METHODS}

The study was a case study that applied Need for Help Wiedenbach and Self Care Orem theory in five pregnancy cases with multi drug resistance tuberculosis at two referral hospitals in Jakarta. These hospitals were practical settings for maternity nursing student. The pregnant women have been treated with a day out three days of minimum care.

\section{RESULTS}

The table 1 describes the result of the acute phase in the identification stage of the need for help theory of Wiedenbach. This study found five nursing diagnosis including oxygenation disorders associated with shortness of breath and cough, pregnancy nutritional disorders associated with nausea and vomiting unwilling to eat, rest and sleep disorders associated with cough and upward fever, and risk of fetal injury associated with pregnancy with infection mycobacterium tuberculosis multi drug resistance.

Nursing interventions for the oxygenation disorders were observing vital signs, placing the client in a $45^{\circ}$ fowler position, providing oxygen using an oxygen hood, 
collaboration for oxygen therapy, inhalation therapy, anti-pyretic therapy and antituberculosis therapy.

Nursing interventions for the diagnosis of pregnancy nuisance disorder were carried out in the form of observing the balance of intake and out put fluids and electrolytes, supporting adequate intake and electrolyte administration, observing nausea and vomiting, medical collaboration of intravenous nutrition, anti-emesis therapy and dietary collaboration of high calorie and protein nutrients stepped up gradually.

Nursing interventions to solve the rest and sleep disorders included carried out by placing the client in a quiet room, placing the client in a $45^{\circ}$ fowler position, supporting adequate oxygen delivery during sleep and rest periods. Finally, nursing interventions to deal with fetal injury risk diagnosis were performed to place bedrest clients with a lying side position to the left, providing oxygen therapy using hoods, monitoring fetal movement and fetal heart rate, performing cardiotocography checks, installing infusions to increase pregnancy nutritional intake, encouraging clients to reduce exhausting physical activity, collaboration of ultrasonography examination, administration of corticosteroid therapy (if necessary), multivitamin administration of pregnancy, dietary collaboration for nutritional high-calorie protein and family collaboration to support the needs of activities that are not exhausting.

Table 1 Assessment Results on Five Cases under Managed Theory Need For Help Wiedenbach

\begin{tabular}{|c|c|c|c|c|c|c|}
\hline \multirow[b]{2}{*}{ No } & \multirow{2}{*}{$\begin{array}{c}\text { Assessment } \\
\text { Results }\end{array}$} & \multicolumn{5}{|c|}{ Patients Managed } \\
\hline & & 1. Miss.F & 2. Miss.R & 3. Miss..B & 4. Miss.Y & 5. Miss.N \\
\hline \multicolumn{7}{|c|}{ Characteristics of Mother } \\
\hline 1 & Age & 28 years & 31 years & 22 years & 22 tahun & 25 years \\
\hline 2 & Parity & G2P0A1 & $\mathrm{G} 2 \mathrm{P} 1 \mathrm{~A} 0$ & G1P0A0 & G1P0A0 & G2P0A1 \\
\hline 3 & Education & High School & High School & High school & SMA & High School \\
\hline 4 & Work & housewife & factory & factory & Pabrik & Private \\
\hline 5 & Type & Pulmonary & Pulmonary & Limfadenitis & Limfadenitis TB & Pulmonary TB \\
\hline & infection & TB & TB & TB & & \\
\hline
\end{tabular}




\begin{tabular}{|c|c|c|c|c|c|c|}
\hline 6 & $\begin{array}{l}\text { Medical } \\
\text { history }\end{array}$ & $\begin{array}{l}\text { Failed } \\
\text { teraphy }\end{array}$ & $\begin{array}{l}\text { Dropped } \\
\text { medicine }\end{array}$ & $\begin{array}{l}\text { Dropped } \\
\text { medicine }\end{array}$ & $\begin{array}{l}\text { Dropped } \\
\text { medicine }\end{array}$ & Dropped medicine \\
\hline \multicolumn{7}{|c|}{ Phisical asessment } \\
\hline 7 & Weakness & $\sqrt{ }$ & $\sqrt{ }$ & $\sqrt{ }$ & $\sqrt{ }$ & $\sqrt{ }$ \\
\hline 8 & Weight loss & $\sqrt{ }$ & $\sqrt{ }$ & $\sqrt{ }$ & $\sqrt{ }$ & $\sqrt{ }$ \\
\hline 9 & Out of breath & $\sqrt{ }$ & $\sqrt{ }$ & $\sqrt{ }$ & $\sqrt{ }$ & $\sqrt{ }$ \\
\hline 10 & $\begin{array}{l}\text { Intermiten } \\
\text { Cough }\end{array}$ & $\sqrt{ }$ & $\sqrt{ }$ & $\sqrt{ }$ & $\sqrt{ }$ & $\sqrt{ }$ \\
\hline 11 & $\begin{array}{l}\text { Fever up and } \\
\text { down }\end{array}$ & $\sqrt{ }$ & $\sqrt{ }$ & $\sqrt{ }$ & $\sqrt{ }$ & $\sqrt{ }$ \\
\hline 12 & $\begin{array}{l}\text { Nausea } \\
\text { vomiting }\end{array}$ & $\sqrt{ }$ & $\sqrt{ }$ & $\sqrt{ }$ & $\sqrt{ }$ & $\sqrt{ }$ \\
\hline 13 & contraction & - & $\sqrt{ }$ & - & - & - \\
\hline 14 & $\begin{array}{l}\text { Fetal heart } \\
\text { rate }\end{array}$ & $146 \mathrm{x} /$ menit & 148 /menit & $146 \mathrm{x} / \mathrm{menit}$ & $146 \mathrm{x} /$ menit & $146 \mathrm{x} / \mathrm{menit}$ \\
\hline 15 & $\begin{array}{l}\text { Index of } \\
\text { amniotic fluid }\end{array}$ & 8 (cenough) & 8 (enough) & 9 (enough) & $\begin{array}{l}6 \\
\text { (oligohidramnion) }\end{array}$ & 2.7(oligohidramnion) \\
\hline 16 & $\begin{array}{l}\text { Tbacil acid } \\
\text { test }\end{array}$ & $(-)(+)(+)$ & $(-)(+)(+)$ & $(+)(+)(+)$ & $(+)(+)(+)$ & $(-)(+)(+)$ \\
\hline 17 & Fhoto torak & $\begin{array}{l}\text { Apek lung } \\
\text { left and right } \\
\text { Infiltration }\end{array}$ & $\begin{array}{ll}\text { Apek lung } \\
\text { left } & \text { and } \\
\text { right } & \end{array}$ & $\begin{array}{l}\text { Apek lung left } \\
\text { and right } \\
\text { Infiltration }\end{array}$ & $\begin{array}{l}\text { Apek lung left } \\
\text { and } \\
\text { Infiltration }\end{array}$ & $\begin{array}{l}\text { Apek lung left and } \\
\text { right Infiltration }\end{array}$ \\
\hline 18 & $\begin{array}{l}\text { Blood of gas } \\
\text { analisis }\end{array}$ & inadequate & $\begin{array}{l}\text { Infiltration } \\
\text { inadequate }\end{array}$ & inadequate & inadequate & inadequate \\
\hline 19 & $C T G$ & $\begin{array}{l}\text { Reaktif } \\
\text { reasuring }\end{array}$ & $\begin{array}{l}\text { Reaktif } \\
\text { easuring }\end{array}$ & $\begin{array}{l}\text { Reaktif } \\
\text { reasuring }\end{array}$ & Takikardi & takikardi \\
\hline
\end{tabular}

Table 2 Assessment Results on Five Cases Under Management with Orem Self Care Theory Design

\begin{tabular}{|c|c|c|c|c|c|c|}
\hline \multirow{2}{*}{ No } & \multirow{2}{*}{ Assesment result } & \multicolumn{5}{|c|}{ Patients Managed } \\
\hline & & 1. Miss.F & 2. Miss.R & 3. Miss.B & 4. Miss.Y & 5. Miss.N \\
\hline \multicolumn{7}{|c|}{ Basic Conditioning Factors } \\
\hline 1 & Age & 28 years & 31 years & 22 years & 26 years & 25 years \\
\hline 2 & Parity & G2P0A1 & $\mathrm{G} 2 \mathrm{P} 1 \mathrm{~A} 0$ & G1P0A0 & $\mathrm{G} 3 \mathrm{P} 2 \mathrm{~A} 0$ & G2P0A1 \\
\hline 3 & Education & $\begin{array}{l}\text { Pulmonaris } \\
\text { TB }\end{array}$ & $\begin{array}{l}\text { Pulmonaris } \\
\text { TB }\end{array}$ & Limfadenitis TB & Pulmonaris TB & Pulmonaris TB \\
\hline 4 & Work & - & $\sqrt{ }$ & - & - & - \\
\hline 5 & Type of infection & $146 \mathrm{x} /$ menit & $148 /$ menit & $146 \mathrm{x} /$ menit & $146 \mathrm{x} /$ menit & $146 \mathrm{x} /$ menit \\
\hline 6 & Medical history & 8 (enough) & 8 (enough) & 9 (enough) & 6/oligohidramnion & 2.7/oligohidramnion \\
\hline 7 & CTG & $\begin{array}{l}\text { Reaktif } \\
\text { reasuring }\end{array}$ & $\begin{array}{l}\text { Reaktif } \\
\text { reasing }\end{array}$ & $\begin{array}{l}\text { Reaktif } \\
\text { reasuring }\end{array}$ & tacicardi & tacicardi \\
\hline \multicolumn{7}{|c|}{ Universal Self Care Requisites } \\
\hline 8 & $\begin{array}{l}\text { Oksigenation } \\
\text { diisorder }\end{array}$ & $\sqrt{ }$ & $\sqrt{ }$ & $\sqrt{ }$ & $\sqrt{ }$ & $\sqrt{ }$ \\
\hline 9 & Nutrition disorder & $\sqrt{ }$ & $\sqrt{ }$ & $\sqrt{ }$ & $\sqrt{ }$ & $\sqrt{ }$ \\
\hline 10 & $\begin{array}{l}\text { Rest and sleep } \\
\text { disorder }\end{array}$ & $\sqrt{ }$ & $\sqrt{ }$ & $\sqrt{ }$ & $\sqrt{ }$ & $\sqrt{ }$ \\
\hline 11 & $\begin{array}{l}\text { Elimintion } \\
\text { disorder }\end{array}$ & - & - & - & - & - \\
\hline 12 & Aktifity disorder & $\sqrt{ }$ & $\sqrt{ }$ & $\sqrt{ }$ & $\sqrt{ }$ & $\sqrt{ }$ \\
\hline
\end{tabular}




\begin{tabular}{|c|c|c|c|c|c|c|}
\hline \multicolumn{7}{|c|}{ Developmental Self Care Requisites } \\
\hline 13 & $\begin{array}{l}\text { Ability to } \\
\text { maintain health }\end{array}$ & unadequate & unadequate & unadequate & unadequate & unadequate \\
\hline \multicolumn{7}{|c|}{ Therapeutic Self Care Demand } \\
\hline 14 & $\begin{array}{l}\text { Awareness of } \\
\text { obedient treatment }\end{array}$ & $\begin{array}{l}\text { Failed } \\
\text { treatment }\end{array}$ & $\begin{array}{l}\text { dropped } \\
\text { medicine }\end{array}$ & $\begin{array}{l}\text { dropped } \\
\text { medicine }\end{array}$ & dropped medicine & dropped medicine \\
\hline \multicolumn{7}{|c|}{ Deviasi Self Care Requisites } \\
\hline 15 & $\begin{array}{l}\text { Readiness to do } \\
\text { self care }\end{array}$ & $\sqrt{ }$ & $\sqrt{ }$ & $\sqrt{ }$ & $\sqrt{ }$ & $\sqrt{ }$ \\
\hline
\end{tabular}

The evaluation and validation of the acute phase based on the theory of need for help wiedenbach found after 24 hours nursing interventions helped patients to overcome the interference oxygenation, nutritional disorders of pregnancy, bed rest disorders and the risk of fetal injury. Then the interventions continued in the maintenance phase by applying Orem self care theory.

Table 2 describes the assessment results in the maintenance phase of the Orem self care theory application. Assessment of the maintenance phase identified three nursing diagnosis including patients' readiness to improve the ability of self-care, the risk of fetal injury associated with mothers' MDR-TB infection and anxiety in dealing with critical situation and treatments.

Nursing intervention on the diagnosis of readiness improve self capability care included health maintenance actions to optimize the client's ability to meet their needs of oxygen, nutrition, sleep and activity breaks.

Interventions in the diagnosis of readiness to improve the ability of self care according to identification of developmental self care included providing health education that explain about the disease, the cause of the disease in pregnancy and fetus, the benefits of completing medication, the benefits of adequate nutrition in pregnancy with tuberculosis, the benefits of clean and healthy lifestyle, and health behaviors to prevent transmission of disease to other family members. 
Nursing interventions to improve self-care skills based on the identification of therapeutic self-care demand were suportive and educative actions to encourage clients' awareness of the importance of health care in pregnancy with MDR-TB by practicing uninterrupted treatment.

Nursing intervention to improve self-care skills based on the identification of self care requisites deviation included encouraging the ability of clients and families of clean and healthy lifestyle and preventing the transmission of tuberculosis in other family members

Evaluation in the maintenance phase based on Orem self care theory showed that after 24 hours of nursing care, clients' ability of self-care increased including respiratory capacity was getting better mean the intervention helped patients to overcome oxygenation disorders. Patients' ability increased related to fullfiling the nutrition in pregnancy. Patients had enough sleep and rest means nursing interventions helped patient to overcome sleep break Finally, patients raised their awareness related treatment adherence and readiness to do self care.

\section{DISCUSSION}

One of characteristics of mycobacterium tuberculosis is patient do not show signs and symptoms especially latent TB infection, as a result the treatment of tuberculosis needs to be done at least for six months without pause.

Cunningham (2010); Anderson (1997); Kemenkes (2013); The Association of Indonesian Physicians (2011) and Rogayah (2014) explained that incomplete treatment, disobedient or failing treatment can lead to bacterial resistance to anti-tuberculosis drugs and cause deterioration of health. 
Tripathy (2003) and Persatuan Dokter Lung Indonesia (2011) explained that the symptoms of tuberculosis in pregnant women are similar to those of tuberculosis in general. The symptoms are influenced by the extent of lesions and the spread of bacteria in the body. This explanation is in accordance with the findings of data on five cases. In this case study the client underwent the same symptoms, only in the case of tuberculosis lymphadenitis, the client also experienced additional symptoms of an inflammatory reaction accompanied by pain in lymphadenitis TB.

Acute-phase of nursing care in pregnancy with MDR-TB is aimed to help patient overcome oxygenation disorders, pregnancy nutrition disorders, sleep restriction and preventing injury to the fetus.

Oxygenation and circulation in pregnant women is important to maintain the life and health of the mother and fetus Cunningham (2010) explained that pregnancy with reactive pulmonary tuberculosis with oxygen and circulatory disturbances is significantly correlated with incidence of preterm birth, low birth weight, fetal development and perinatal mortality.

Nutrition in pregnancy is important to support the physiological activity of the mother and fetus. Shinagawa (2006) explained that the normal response of pregnant women's bodies that require to increase fetal and placental nutrient lead to significant metabolic changes. The chenges included increasing basal metabolic uptake $10 \%-20 \%$ compared with nonpregnant metabolic conditions. It would increase another $10 \%$ in pregnant women with a twin fetus.

Hytten and Chamberlain (1991) explained that it is necessary to pregnant women adding total energy up to 80,000 kilo calories or about 300 kilo calories per day during pregnancy to meet the basal metabolic. Mother's weight commonly increases in 
the normal pregnancy. Yet, it is different in the case of pregnancy with tuberculosis multi drug resistance. Mycobacterium tuberculosis infection affected nausea and vomiting in pregnant women as a result pregnant women's weight significant loss.

Cunningham (2010) stated that malnutrition in pregnancy threaten the pregnant women and increase the risk of preterm labor, low birth weight, fetal development and increased risk of perinatal death. Based on these explanations, the nurse needs to provide nursing care that would improve the nutritional status of pregnant women with multi-drug resistant tuberculosis so malnutrition of pregnancy and fetal distress does not occur.

Jana, at.al (1994) and Damian (1998) argued that reactive lung tuberculosis is closely associated with increasing incidence of preterm birth, low birth weight, infant development and perinatal mortality. The explanation shows the importance of providing nursing care to overcome oxygenation disorders in pregnant women with multi-drug tuberculosis resistance. If the oxygenation disorders can not be solved soon, then fetal risks of distress.

Nursing implementations assisted pregnant women to prevent fetal distress by placing the mother on the left side of the bed, giving oxygen therapy using the hood, observing fetal well-being by observing mother's vital signs, monitoring fetal heart rate and fetal movement using hi- tech and medical collaboration of pregnancy tests that may explain the fetal heart rate, fetal heart rhythm, fetal position in the womb, amniotic fluid volume and estimated fetal weight using cardiotocography and ultrasonography.

The evaluation and validation stage found that nurses achieved the aims of nursing care plan in the acute phase the theory of need for help Wiedenbach. This is 
proved that the application of Wiedenbach's need for help theory is effective for use in acute phase nursing care in pregnant women with multi drug drug resistance.

\section{CONCLUSION}

The integration of theories need for help Wiedenbach and Orem self care in five cases of pregnancy with multi-drug resistant tuberculosis proved overcome the health deterioration in the acute phase effectively and increase the potential of self-care clients and families in the maintenance phase.

\section{REFERENCE}

Alligood, M. R. \&Tomay, A. M. (2010).Nursing theorists and their work. Missouri: Mosby Elsevier.

Anderson.G.D(1997) Tuberculosis In pregnancy.Seminar Perinatology .21: 328. 1997.

Badan Penelitian dan Pengembangan Kesehatan Departemen Kesehatan Republik Indonesia.(2010).Laporan nasional riset kesehatan dasar RISKESDAS 2012. Jakarta: Kementerian kesehatan Republik Indonesia.

Badan Penelitian dan Pengembangan Kesehatan Departemen Kesehatan Republik Indonesia.(2013). Laporan nasional riset kesehatan dasar RISKESDAS 2013. Jakarta: Kementerian kesehatan Republik Indonesia.

Cunningham., Leveno., Bloom., Hauth., Rouse.,Spong. (2010). Obstetri Williams Edisi 23. Jakarta: EGC

Deepaty, Glory Prasad. 2008. Study to evaluate the effectiveness of planned Teaching programme on knowledge of active management Of third stage of labour in prevention of post partum Hemorrhage among staff nurses working in the K.L.E.S Hospital and Mrc, Belgaum, Karnataka. Dissertations .Rajiv Gandhi University of Health Sciences, Karnataka, angalore.Retrieved from http://hdl. handle. net/ $123456789 / 4277$

Departemen kesehatan RI (2008) Direktorat Jenderal Pengendalian Penyakit dan Penyehatan lingkungan. Rencana Aksi Nasional Programmatic Management Drug Resistance Tuberculosis Pengendalian Tuberculosis Indonesia 20112014, Jakarta: Depkes RI; 2008 
Direktorat Jendral Pengendalian Penyakit dan Penyehatan Lingkungan (2011) Rencana Aksi Nasional Programatic Management Drug Resistance Tuberculosis Pengendalian Tuberculosis Indonesia 2011-2014, Jakarta: Depkes RI; 2011

Ghosh K, Ghosh K, Chodwuri JR (2011) Tuberculosis and female reproductive health. Journal of postgraduate medicine oktober 2011 vol.57 issue 4

Hytten FE (1991) weight gain in pregnancy. In Hytten FE, Chamberlain G (eds): clinical physiology in obstetrics, $2^{\text {nd }}$ ed.Oxford, Blackwell, 1991,p 173

international NGO forum on Indonesian Development.(2016) out come document transforming our world: the 2030 agenda for Sustainable Development Goals.

Jana N, Vasishta K, Jindal SK, et al (1994) perinatal outcomes in pregnancies complicated by pulmonary tubercu losis. Int. JGynecolObstet 44:119, 1994

Kementrian Kesehatan RI Direktorat P2PL (2011) pedoman nasional pengendalian Tuberkulosis.Keputusan enteri Kesehatan RI nomor 021/ Menkes / SK / 1 / 2011 tentang rencana strategis Kemen trian Kesehatan Tahun 20102014. Kementerian Kesehatan, Jakarta 2011.

Kothari A, Mahadewan N, Girling J (2006) Tuberculosisi in pregnancy-Result of a study in high prevalence area in London. Eur J Obstet Gynecol ReprodBiol $2006 ; 126 ; 48-55$

LLewyn M, Gropley I, Wilkinson RJ, Davidson RN (2000) Tuberculosis diagnosed during pregnancy. A Prospective study from London. Thorax 2000; 55;126;4855

Munir SM (2009) Pengamatan Pasien Tuberculosis Paru dengan Multi Drug Resistance (TB-MDR) di poli klinik paru RS.Persahabatan.Tesis Departemen Pulmonologi dan Kedokteran Respirasi tahun 2009

North American Nursing Diagnosis Association (1992) $10^{\text {th }}$ Confrence on classification of nursing diagnoses. San Diego: California, 1992.Definition from a standard taxonomy of nursing problem.

Perhimpunan Dokter Paru Indonesia (2012) Pedoman diagnosis dan penatalak sanaan di Indonesia.Jakarta: PDPI

Rogayah Rita (2014) Analisis mutu pelayanan TB-MDR dengan strategi program matic management of drug resistant tuberculosis di RSUP Persahabatan.Jakarta.

Shinagawa S, Suzuki S, Chihara H, et al (2006) Maternal Basal Metabolic Rate in Twin Pregnancy. Gynecol Obstet Invest 60:145, 2006, 604162.doi:10.1153/2006/60152 
Survey Dasar Kesehatan Indonesia (2012).Profil Kesehatan Indonesia 2012. Jakarta: Kementerian Kesehatan Republik Indonesia.

Tripathy SN (2003) Tuberculosis and pregnancy. Int. J GynaecolObstet 2003; 80; 24753.doi: 10.1004 /s12 72/2003/60342

World Health Organisation (2014) Global Tuberculosis report 2012. Geneva :WHO press; 2010.p.1-50(1).World Health Organization. Guidlines for the programmatic management of drug resistance tuberculosis.Emergency up date. 2008

World Health Organization (2009) World Health Report. 2000.12368. 